http://dx.doi.org/10.11646/zootaxa.3784.4.2

http://zoobank.org/urn:lsid:zoobank.org:pub:D24E3364-03AC-48E3-891C-DF4E20EE604F

\title{
The Odonata (Insecta) of Patagonia: A synopsis of their current status with illustrated keys for their identification
}

\author{
JAVIER MUZÓN ${ }^{1}$, PABLO PESSACQ ${ }^{2} \&$ FEDERICO LOZANO ${ }^{1}$ \\ 'Instituto de Limnología "Dr. Raul A. Ringuelet" (CCT-La Plata), CC 712 - 1900 La Plata, Argentina. \\ E-mail:muzon@ilpla.edu.ar; federicolozano82@gmail.com \\ ${ }^{2}$ Laboratorio de Investigaciones en Ecología y Sistemática Animal (LIESA). Sarmiento 849, 9200, Esquel, Chubut, Argentina \\ E-mail: pablopessacq@yahoo.com.ar
}

\begin{abstract}
Patagonia is a vast landmass with a distinctive environmental and biotic heterogeneity. Its Odonata biodiversity is the best known of South America, and it is composed of 36 species, of which more than $50 \%$ are endemic. We summarize the main taxonomic, distributional and biological information including illustrated keys for adults and known larvae, and distributional maps.
\end{abstract}

Key words: Zygoptera, Anisoptera, larva, adult, southern Argentina, southern Chile, key, distribution maps

\section{Introduction}

Patagonia represents one of the main austral landmasses of the World. It is characterized by a distinctive environmental heterogeneity consisting of a narrow ecotone between two main biomes: the subantarctic forests and the arid or semiarid areas of the steppe. This ecotone runs parallel a few kilometers east of the Andes, so arid areas of Patagonia are mostly developed in Argentina, with the exception of part of Magallanes region in southern Chile which is also arid. The environmental heterogeneity is clearly reflected in almost all biotic components, which contain subantarctic and neotropical representatives.

The order Odonata is represented in Patagonia by 36 species arranged in nine families and 18 genera (Table 1. Authors' names and year of description for each species are only included in this table). Approximately $60 \%$ of the species and 40\% of the genera are endemic (Muzón 1995; 1997a; 2009), the monotypic family Neopetaliidae being one of the most remarkable endemisms. We do not expect to find any as yet undescribed species here, but new records are still likely, such as Phyllopetalia altarensis (Carle 1996), a central Chilean species, or some subtropical species in northern Patagonia in Argentina (e.g., Colorado river basin).

Biogeographical aspects of Patagonian odonates have been treated previously (Jurzitza 1989a; Muzón 1995, 1997a, 2009; Muzón et al. 2005). They follow a general biodiversity pattern characterized by two main faunistic components: the subantarctic, restricted to the Nothofagus forest on both slopes of the Andes, and a widespread neotropical component mainly distributed in the steppe (Table 1). The subantarctic faunistic component can be tracked further north up to central Chile (Roig 1994; Roig \& Flores 2001) whereas the neotropical one is represented either by widespread species, e.g., Ischnura fluviatilis, Lestes undulatus, Rhionaeschna absoluta, or by species more restricted in distribution, e.g., Andinagrion peterseni, and Patagonic endemics, e.g., Cyanallagma interruptum, Erythrodiplax connata, Sympetrum villosum.

The most significant biodiversity patterns observed in Patagonia are the latitudinal species richness decline, from more than 30 species in the north to only one, Rhionaeschna variegata, in Tierra del Fuego island, and the striking differences between the composition and richness of the forest and steppe taxocoenosis; these patterns determine two diversity gradients: north to south and west to east, resulting in highest differences among northwestern (more rich and diverse) and southeastern areas. These gradients could be partially explained by the 
The genus Gomphomacromia was revised by von Ellenrieder \& Garrison (2005), who synonymized G. mexicana Needham, 1933, with G. chilensis, and G. etcheverry Fraser, 1957, with G. paradoxa. Gomphomacromia chilensis is a poorly known species endemic to central Chile, reaching Patagonia at its northern border, approximately $35^{\circ} \mathrm{S}$; locality data are few. Gomphomacromia paradoxa occurs all along the Andean range approximately from $32^{\circ}$ to $51^{\circ} \mathrm{S}$.

The larvae of Gomphomacromia paradoxa and Rialla villosa have been described (Needham \& Bullock 1943; Theischinger \& Watson 1984); that of G. chilensis remains unknown.

Gomphomacromia paradoxa inhabits mountain streams, seepages and bogs, and it can be found in large numbers; males defend their territory and tandems land by the side of the streams (von Ellenrieder \& Garrison 2005). Larvae of this species seem to be semi-terrestrial (von Ellenrieder \& Garrison 2005).

Rialla villosa inhabits lakes and ponds in the Nothofagus forest. Adults fly straight close to the water; copulation takes place during flight; tandems perch on trees (Jurzitza 1975), adults perch occasionally on grass and bushes, usually in vertical position (Jurzitza 1989a). Larvae were collected in oligotrophic lakes with the aid of dredges from 20 m depth (Muzón 1995).

\section{Acknowledgements}

We thank Natalia von Ellenrieder, Rosser W. Garrison and Gustavo R. Spinelli for critical reading of the manuscript. We also thank Alejandro del Palacio for his valuable comments on Patagonian Erythrodiplax. This work was supported by grants from CONICET (National Research Council of Argentina), Eppley Foundation for Research, National Geographic Society and Darwin Initiative.

\section{References}

Baird, I.R.C. (2013) Larval habitat and behaviour of Phenes raptor (Odonata: Petaluridae): a review of current knowledge, with new observations. International Journal of Odonatology, 16 (1), 79-91. http://dx.doi.org/10.1080/13887890.2012.757723

Bechly, G. (1996) Morphologische Untersuchungen am Flügelgeäder der rezenten Libellen und deren Stammgruppenvertreter (Insecta; Pterygota; Odonata), unter besonderer Berücksichtigung der Phylogenetischen Systematik und des Grundplanes der Odonata. Petalura, 2, 1-402.

Belle, J. (1992) Studies on ultimate instar larvae of neotropical Gomphidae, with the description of Tibiagomphus gen. nov. (Anisoptera). Odonatologica, 21 (1), 1-24.

Borror, D.J. (1942) A revision of Libelluline genus Erythrodiplax (Odonata). Ohio State University Graduate Studies, Contributions in Zoology and Entomology 4, Biological Series, $x v+286$ pp.

Böttger, K. \& Jurzitza, G. (1967) Beitrag zur Faunistik, Ökologie und Biologie der Odonaten von Südchile. Beitrage zur Neotropischen Fauna, 5, 22-44. http://dx.doi.org/10.1080/01650526709360394

Brauer, F. (1864) Erster Bericht über die auf der Weltfahrt der kais. Fregatte Novara gesammelten Neuropteren. Verhandlungen der Zoologisch-Botanischen Gesellschaft in Wien, 14 (Abhandl.), 59-164.

Brauer, F. (1868) Verseichnissder bits jetzt bekannten Neuropteren im Sinne Linne's. Verhandlungen der ZoologschBotanischen Gesellschaft in Wien, 18 (359-416), 711-742.

Bulla, L.A. (1973a) Cinco ninfas nuevas o poco conocidas del género Oxyagrion Selys (Odonata, Coenag.). Revista del Museo de La Plata, 12 (112), 11-25.

Bulla, L.A. (1973b) Revisión de dos especies Argentinas del género Cynallagma Kennedy (Odonata, Coenagriidae). Revista de la Sociedad Entomológica Argentina, 34 (1-2), 95-105.

Burmeister, H.C.C. (1839) Neuroptera. In: Handbuch der Entomologie. T.C.F. Enslin, Berlin, pp. 757-1050.

Calvert, P.P. (1956) The neotropical species of the "sub-genus Aeshna" sensu Selysii 1883 (Odonata). Memoirs of the American Entomological Society, 15, 1-251.

Campion, H. (1922) Notes on a small collection of Odonata from Argentina. Annals and Magazine of Natural History, 9 (10), 290-295.

Carle, F.L. (1996) Revision of Austropetaliidae (Anisoptera: Aeshnoidea). Odonatologica, 25 (3), 231-259.

Carle, F.L. \& Cook, C. (1984) A new Neogomphus from South America, with extended comments on the phylogeny and biogeography of the Octogomphini trib. nov. (Anisoptera: Gomphidae). Odonatologica, 13 (1), 55-70.

Carle, F.L. \& Louton, J.A. (1994) The larva of Neopetalia punctata and establishment of Austropetaliidae Fam. Nov. 
(Odonata). Procedings of the Entomological Society of Washington, 96 (1), 147-155.

Charpentier, T. de (1840) Libellulinae Europeaceae descriptae et depictae. Lipsiae, Leopold Voss, 180 pp.

Carvalho, A.L., Ferreira, N. Jr. \& Nessimian, J.L. (1991) Descrição das larvas de três espécies do gênero Erythrodiplax Brauer (Odonata: Libellulidae). Revista brasileira de Entomologia, 35 (1), 165-171.

del Palacio, A. \& Muzón, J. (2012) Delimitación del área de distribución de Erythrodiplax connata (Burmeister) (Odonata Libellulidae). VIII Congreso Argentino de Entomología, S.C. de Bariloche, pp. 380

Dijkstra, K.D.B., Bechly, G., Bybee, S.M., Dow, R.A., Dumont, H.J., Fleck, G., Garrison, R.W, Hämäläinen, M., Kalkman, V.J., Karube, H., May, M.L., Orr, A. G., Paulson, D.R., Rehn, A.C., Theischinger, G. Trueman, J.W.H., Van Tol, J., von Ellenrieder, N. \& Ware, J. (2013) The classification and diversity of dragonflies and damselflies (Odonata). Zootaxa, 3703 (1), 36-45.

http://dx.doi.org/10.11646/zootaxa.3703.1.9

Fabricius, J.C. (1775) Systema Entomologiae. Flensburg and Leipzig, Library Kortii, 832 pp.

Förster, F. (1909) Bëitrage zu den Gattungen und Arten der Libellen. Jahrbücher des nassauischen Vereins für Naturkunde. Wiesbaden, 62, 211-235.

Fraser, F.C. (1957) A revision of the Odonata of Chile. Revista Universitaria, 42, 153-166.

Garré, A., Muzón, J. \& Ardohain, M. (2008) Description of the final instar larvae of Erythrodiplax atroterminata Ris and E. corallina (Brauer) (Odonata: Libellulidae). Zootaxa, 1896, 45-50.

Garrison, R.W., von Ellenrieder, N. \& Louton, J.A. (2006) The dragonfly genera (Odonata: Anisoptera) of the New World. An illustrated and annotated key. The Johns Hopkins University Press, Baltimore, 384 pp.

Garrison, R.W. \& Muzón J. (1995) Collecting down at the other "down under". Argia, 7, 23-26.

Herrera, J., Etcheverry, M. \& Carrasco, H. (1955/1956) Los odonatos de Chile. Revista Universitaria, 40/41, $20,63-88$.

IUCN (2013) The IUCN Red List of Threatened Species. Version 2013.2. Available from: http://www.iucnredlist.org (accessed 13 December 2013)

Jurzitza, G. (1974) Antiagrion gayi (Selys, 1876) und A. grinbergsi spec. nov., zwei Verwechlungsarten aus Chile (Zygoptera: Coenagrionidae). Odonatologica, 3 (4), 221-230.

Jurzitza, G. (1975) Ein Beitrag zur Faunistik und Biologie der Odonaten von Chile. Stuttgarter Beiträge zur Naturkunde, Ser. A., 280, 1-20.

Jurzitza, G. (1989a) Versuch einer Zusammenfassung unserer Kenntnisse über die Odonatenfauna Chiles. Societas Internationalis Odonatologica Rapid Communications (Suppl.), 9, 1-32.

Jurzitza, G. (1989b) Phenes raptor centralis n. Subsp. aus Chile (Odonata: Petaluridae). Entomologische Zeitschrift, 99 (12), $161-176$.

Karsch, F. (1889) Beitrag zur Kenntniss der Libellulinen mit vierseitiger cellula cardinalis (Nannophya Rambur). Entomologische Nachritchen, 15 (16), 245-264.

Kennedy, C.H. (1920) Forty-two hitherto unrecognized genera and subgenera of Zygoptera. Ohio Journal of Science, 21 (2), 83-88.

Leach, W.E. (1815) Entomology. In: Brewster, D. (Ed.), The Edinburgh Encyclopedia. Vol. IX. Part I. Edinburgh, 57-172.

Lozano, F., Muzón, J. \& del Palacio, A. (2011) Description of final stadium larva of Erythrodiplax connata and E. basifusca and redescription of that of E. minuscula (Odonata: Libellulidae). International Journal of Odonatology, 14 (2), $127-135$. http://dx.doi.org/10.1080/13887890.2011.595354

Martin, R. (1921) Sur les odonates du Chili. Revista Chilena de Historia Natural, 25, 19-25.

Matushkina, N.A. \& Klass, K.D. (2011) Morphology of female external genitalia in Phenes raptor (Odonata: Petaluridae). International Journal of Odonatology, 14 (3), 199-215. http://dx.doi.org/10.1080/13887890.2011.607735

McLachlan, R. (1870) Descriptions of a new genus and four new species of Calopterygidae, and a new genus and species of Gomphidae. Transactions of the Entomological Society of London, 18, 165-172. http://dx.doi.org/10.1111/j.1365-2311.1870.tb01871.x

Muzón, J. (1995) Los Odonata de la Patagonia argentina. Revista de la Sociedad Entomológica Argentina, 54 (1-4), 1-14.

Muzón, J. (1997a) Odonata from Patagonia: Species richness and distributional patterns. Biogeographica, 73 (3), $123-133$.

Muzón, J. (1997b) Redescripción de Lestes auritus y Lestes paulistus y descripción del último estadio larval de L. undulatus (Odonata: Lestidae). Revista de la Sociedad Entomológica Argentina, 56 (1-4), 159-166.

Muzón, J. (2009) Estado actual del conocimiento del orden Odonata en la Patagonia. Revista de la Sociedad Entomológica Argentina, 68 (1-2), 163-167.

Muzón, J. \& Lozano, F. (2011) Description of the final instar larva of Progomphus joergenseni Ris (Epiprocta: Gomphidae). Zootaxa, 2762, 56-60.

Muzón, J. \& Spinelli, G.R. (1995) Patagonian Odonata in Malaise traps. Argia, 7 (3), 22-23.

Muzón, J., Spinelli, G.R., Pessacq, P., von Ellenrieder, N., Estévez, A.L., Marino, P.I., Perez Goodwyn, P.J., Angrisano, E.B., Díaz, F., Fernández, L.A., Mazzucconi, S., Rossi, G. \& Salomón, O.D. (2005) Insectos acuáticos de la Meseta de Somuncurá, Patagonia, Argentina. Inventario preliminar. Revista de la Sociedad Entomológica Argentina, 64 (3-4), 4768.

Muzón, J., Spinelli, G.R., Rossi, G., Marino, P.I., Díaz, F. \& Melo, M.C. (2010) Nuevas citas de insectos acuáticos para la Meseta de Somuncurá, Patagonia, Argentina. Revista de la Sociedad Entomológica Argentina, 69 (1-2), 111-116. 
Muzón, J. \& von Ellenrieder, N. (1996) Estadios larvales de Odonata de la Patagonia. I. Descripción de Aeshna variegata Fabricius (Odonata: Aeshnidae). Revista de la Sociedad Entomológica Argentina, 56 (1-4), 143-146.

Muzón, J. \& von Ellenrieder, N. (1997) Description of the last larval instar of Sympetrum villosum Ris (Odonata: Libellulidae). Neotropica, 43 (109-110), 43-45.

Muzón, J. \& von Ellenrieder, N. (1998) Odonata. In: Morrone, J.J. \& Coscarón, S. (Eds.), Biodiversidad de artrópodos argentinos. Una perspectiva biotaxonómica, Ediciones Sur, La Plata, pp. 14-21.

Muzón, J. \& von Ellenrieder, N. (1999) Status and distribution of Odonata (Insecta) within natural protected areas in Argentina. Biogeographica, 75 (3), 119-128.

Navás, L. (1915) Neue Neuropteren. Entomologischen Mitteilungen 4 (4-6), 146-153.

Needham, J.G. \& Bullock, D.S. (1943) The Odonata of Chile. Zoological Series of Field Museum of Natural History, 24 (32), $357-373$.

Newman, E. (1833) Entomological Notes. Entomological Monthly Magazine, 1 (5), 505-514.

Paulson, D.R. (2004) Critical species of Odonata in the Neotropics. In: Clausnitzer \& Jödicke (Eds.), Guardians of the watershed. Global status of dragonflies: critical species, threat and conservation. Special issue: IUCN Regional Reports. International Journal of Odonatology, 7, 163-188.

Pessacq, P. \& Brand, C. (2009) Description of the larva of Phyllopetalia apollo Selys and redescription of that of Hypopetalia pestilens McLachlan (Anisoptera: Austropetaliidae). Odonatologica, 38 (3), 235-246.

Rambur, M.P. (1842) Histoire naturelle des insectes Neuropteres. Roret, Paris, 534 pp.

Riek, E.F. \& Kukalová-Peck, J. (1984) A new interpretation of dragonfly wing venation based upon early Carboniferous fossils from Argentina (Insecta: Odonatoidea) and basic character states in pterygote wings. Canadian Journal of Zoology, 62, $1150-1166$. http://dx.doi.org/10.1139/z84-166

Ris, F. (1904) Odonaten. In: Hamburg Magallaenischen Sammelreise 1892/93. Friedrichsen \& Co., Hamburg, 44 pp.

Ris, F. (1928) Zwei neue odonaten aus Chile und der argentinischen Kordillere. Entomologische Mitteilungen, 17, $162-174$.

Rodrigues Capítulo, A. (1980) Contribución al conocimiento de los Anisoptera de la República Argentina. I. Descripción de los estadios preimaginales de Aeshna bonariensis Rambur (Insecta Odonata). Limnobios, 2 (1), 1-21.

Rodrigues da Fonseca, R. \& Pujol-Luz, J.R. (1999) Notas sobre a larva de Ischnura fluviatilis Selys, 1876 (Odonata, Coenagrionidae). Contribuições Avulsas sobre a História Natural do Brasil, Série Zoología, 1, 1-4.

Roig, S.J. (1994) Historia biogeográfica de América del Sur Austral. Multequina, 3, 167-203.

Roig, S.J. \& Flores, G.E. (2001) Historia biogeográfica de las áreas áridas de América del Sur Austral. In: Llorente Bousquets, J. \& Morrone, J.J. (Eds.), Introducción a la biogeografía en Latinoamérica: Teorías, conceptos, métodos y aplicaciones. Facultad de Ciencias UNAM, México, pp. 257-266.

Schmidt, E. (1941) Petaluridae, Gomphidae und Petaliidae der Schönemannschen Sammlung aus Chile (Ordnung Odonata). Archiv für Naturgeschichte, N. F., 10 (2), 231-258.

Selys-Longchamps, E. de (1854) Monographie des Calopterygines. Mémoires de la Société Royale des Sciences de Liége, 9, i$\mathrm{xi}+1-291$.

Selys-Longchamps, E. de (1858) Monographie des Gomphines. Brussels and Leipzig, Nuquardt; Paris, Roret, 460 pp.

Selys-Longchamps, E. de (1876) Synopsis des Agrionines, 5me légion: Agrion (suite). Le genre Agrion. Bulletin de l'Ácadémie Royale de Belgique, (2) 41: 247-322, 496-539, 1233-1309, (2) 42: 490-531, 952-991.

Spinelli, G.R. \& Muzón, J. (2000) A viewpoint on Patagonian biogeography from the Ceratopogonidae case (Insecta: Diptera). Biogeographica, 76, 125-132.

Theischinger, G. \& Watson J. A. L. (1984) Larvae of Australian Gomphomacromiinae, and their bearing on the status of the Synthemis group of genera (Odonata: Corduliidae). Australian Journal of Zoology, 32, 67-95. http://dx.doi.org/10.1071/zo9840067

von Ellenrieder, N. (2001a) A synopsis of the Patagonian species of the genus Aeshna Fabricius (Anisoptera: Aeshnidae). Odonatologica, 30 (3), 299-325.

von Ellenrieder, N. (2001b) Species composition and distribution patterns of the Argentinian Aeshnidae (Odonata: Anisoptera). Revista de la Sociedad Entomológica Argentina, 60 (1-4), 39-60.

von Ellenrieder, N. (2001c) The larvae of Patagonian species of the genus Aeshna Fabricius (Anisoptera: Aeshnidae). Odonatologica, 30 (4), 423-434.

von Ellenrieder, N. (2003) A synopsis of the Neotropical species of 'Aeshna' Fabricius: The genus Rhionaeschna Förster (Odonata: Aeshnidae). Tijdschrift voor Entomologie, 146, 67-207. http://dx.doi.org/10.1163/22119434-900000120

von Ellenrieder, N. (2005) Taxonomy of the South American genus Phyllopetalia (Odonata: Austropetaliidae). International Journal of Odonatology, 8 (2), 311-352. http://dx.doi.org/10.1080/13887890.2005.9748258

von Ellenrieder, N. (2007) Some Libellulidae larvae from the Yungas forest, Argentina: Macrothemis hahneli Ris, Brechmorhoga nubecula (Rambur) and Dasythemis mincki clara Ris (Anisoptera). Odonatologica, 36 (3), $263-273$.

von Ellenrieder, N. \& Garrison, R.W. (2005) A synopsis of the South American genus Gomphomacromia (Odonata: Gomphomacromiinae). International Journal of Odonatology, 8 (1), 81-96.

http://dx.doi.org/10.1080/13887890.2005.9748245 
von Ellenrieder, N. \& Garrison, R.W. (2007) Dragonflies of the Yungas. A field guide to the species from Argentina. Pensoft, Sofia, Moscow, $168 \mathrm{pp}$.

von Ellenrieder, N. \& Garrison, R.W. (2008) Oreiallagma gen. nov. with a redefinition of Cyanallagma Kennedy 1920 and Mesamphiagrion Kennedy 1920, and the description of M. dunklei sp. nov. and M. ecuatoriale sp. nov. from Ecuador (Odonata: Coenagrionidae). Zootaxa, 1805, 1-51.

von Ellenrieder, N. \& Muzón, J. (2000) Description of the last instar larva of Erythrodiplax nigricans (Rambur) (Anisoptera: Libellulidae). Odonatologica, 29 (3), 267-272.

von Ellenrieder, N. \& Muzón, J. (2003) Description of the last larval instar of Ischnura fluviatilis Selys (Zygoptera: Coenagrionidae). Bulletin of American Odonatology, 7 (3), 57-60.

von Ellenrieder, N. \& Muzón, J. (2006) The genus Andinagrion, with description of A. garrisoni sp. nov. and its larva from Argentina (Zygoptera: Coenagrionidae). International Journal of Odonatology, 9 (2), 205-223. http://dx.doi.org/10.1080/13887890.2006.9748279

von Ellenrieder, N. \& Muzón, J. (2008) An updated checklist of the Odonata from Argentina. Odonatologica, 37 (1), $55-68$.

Watson, M.C. (1956) The utilization of mandibular armature in taxonomic studies of anisopterous nymphs. Transaction of the American Entomological Society, 81, 155-202. 